\title{
Trade Liberalization and Carbon Dioxide Emissions: A Pooled Mean Group Analysis
}

\author{
Elsayed Mettwally Abd-Elkader
}

\begin{abstract}
This paper aims to estimate the effect of trade liberalization on carbon dioxide $\mathrm{CO}_{2}$ emissions, using the pooled mean group PMG estimator, for 15 developed and 10 developing countries, over the period 1970 to 2013. The paper concluded that, in the long run, the scale effect dominates the technique effect for all countries, there is no evidence for the composition effect for developed countries, whereas it holds for developing countries, trade intensity have a negative effect for developed countries, whereas it have a positive effect for developing countries, and no evidence for environmental regulations Effect ERE or capital labour ratio effect KLE for all countries. The last results reflect the lack of regulations aimed directly at $\mathrm{CO}_{2}$ emissions or, $\mathrm{CO}_{2}$ intensive sectors have not directly faced pressures to relocate.
\end{abstract}

Index Terms-Pooled mean-group estimator PMG, trade liberalization, $\mathrm{CO}_{2}$ emissions panels, environmental regulations effect.

\section{INTRODUCTION}

Increasing movement in the direction of globalization today has made it impossible for countries to be totally independent. One important drivers of globalization is the expansion in world trade. World trade has grown more than twenty-seven fold in volume terms during 1950-2010. The level of world GDP rose eight-fold during the same period. The share of international trade in world GDP has risen from $5.5 \%$ in 1950 to $20.5 \%$ in 2006. Between 2005 and 2010, world merchandise exports continued to grow faster than world GDP, despite the global crisis. Exports growth rates were $3 \%$ during this period whereas GDP growth lagged behind at $2 \%$. In 2009 , merchandise exports fell by $12 \%$ and GDP by $2 \%$ in response to the financial crisis. This was followed by a quick recovery in 2010 , with merchandise exports growing by $14 \%$ and GDP by $4 \%$ [1].

Among the many factors that lead to the expansion in world trade is the trade liberalization (openness). Countries have opened up their trade regimes unilaterally, bilaterally, regionally, and multilaterally. Trade liberalization has been taken through the reduction or elimination of tariffs and non-tariffs barriers. These changes in trade policies have facilitated trade and broadened the number of countries participating in global trade expansion. In particular, developing countries now account for $36 \%$ of world exports, about double their share in the early 1960s [23].

The world environmental deregulation measured by carbon dioxide $\mathrm{CO}_{2}$ emissions, from fossil fuel use and

Manuscript received October 21, 2017; revised December 8, 2017.

Elsayed Mettwally Abd-Elkader is with High Institute for Computer \& Management Science, Shoubra-Al Khaimah, Cairo, Egypt (e-mail: elsyedmett@gmail.com). cement production, increased from 10.6 billion tons in 1965 to 19.8 billion tons in 1980 to 22.5 billion tons in 1990 . Global carbon emissions from fossil fuel use were 35.9 billion tons of $\mathrm{CO}_{2}$ in 2014. An averaged over the last decade, emissions from fossil fuels and industry account for $91 \%$ of human-caused $\mathrm{CO}_{2}$ emissions, with $9 \%$ coming from land use change. Of the 35.7 billion tones of $\mathrm{CO}_{2}$ emitted from fossil fuels in 2014, $41 \%$ came from coal, $34 \%$ from oil, $19 \%$ from gas, $5.6 \%$ from cement production and $0.7 \%$ from flaring [2].

The expansion of world trade and growth of pollution emissions may be one reason why trade is increasingly being raised in climate change negotiations and may also help to explain why there are concerns about the impact of trade on pollution emissions.

There could be two opposing groups studying the relationship between openness and environment. The first group has thought that openness and economic growth would negatively (bad effect) affect environmental quality. Openness may lead to destruction and irrevocable impacts on the environment. The second group has thought that economic welfare can be improved with trade liberalization. Especially developing and less developed countries have low environmental regulations, free trade will raise the income in these countries and with the improving living conditions the households will demand higher environmental standards and eventually the environment will improve [3].

Many earlier empirical studies, failed to find a strong significant relationship between environmental outcomes and trade liberalization. There is no direct link between trade and environment, and in order to be able to paper it, it must be decomposed this complex relationship. There are very few empirical studies on the determinants of emissions based on the theoretical framework. These earlier studies [4]-[6] used a large number of variables, its squared and interactions of these variables and its squared as independent variables, in the equation estimated, and used a complex mathematical formulas to derivative the effects of trade liberalization as elasticities. Finally, these earlier studies generally focus on the traditional random effect (FE) or fixed effect (RE) estimators.

The contribution of this paper is therefore as follows: uses a very simple theoretical framework for relationship between trade liberalization and emissions by modifying the equation used by [4] and employs two important new estimators, which was introduced by [7], [8] to estimate dynamic panels: the mean-group (MG) and pooled mean-group (PMG) estimators. The rest of this paper includes: Section II: How does trade affect pollution emissions? Section III: provides a brief review of previous studies that investigate the relationship between trade liberalization and the environment. In the section IV: Model, data and Econometric method. 
Section V and VI presents results and conclusions.

\section{How Does Trade AfFect Pollution Emissions?}

The amount of emissions an economy generates depends on three essential factors: First, the size of the economy. This is the scale effect which refers to an increase in emissions associated with a larger GDP. Second: the share of output that is produced by emission-intensive or dirty sectors. This is the composition effect, which refers to a change in the share of dirty goods in GDP, and may come about because of a price change favoring their production. Third: the degree of emissions intensity in those sectors. This is the technique effect, which refers to the idea that anything raising per-capita income in the economy generates an endogenous increase in environmental taxes, thereby reducing the pollution intensity of production.

International trade economists, [9]-[11] have developed a conceptual framework for the estimating the scale, composition and technique effects of the Free Trade Agreement of North America (NAFTA). This framework can be used to study the relationship between openness and pollution as follows:

The trade-induced scale effect: refers to the impact on the level of pollution from the increased GDP resulting from freer trade. Trade liberalization opens new previously restricted markets and increases the growth of national output. Increased scale of production may place greater stress on the environment as more inputs and resources are required to satisfy the final demand for new international markets. The general presumption is that trade openness will increase economic activity. Everything else being equal, this increase in the scale of economic activity will lead to higher levels of pollution emissions.

The trade-induced composition effect: This effect explains how emissions are affected by the composition of output, which is determined by the degree of trade openness as well as by the comparative advantage of the country as follows:

First: The capital-labor effect (KLE) or the factor endowment hypothesis: It is expected that countries with abundant capital to have a comparative advantage in the production and export of capital-intensive goods (i.e., pollution goods) and, therefore, to produce more emissions. Trade openness would strengthen the effects of this comparative advantage and would increase the production share of the pollution goods.

Second: The environmental regulations effect (ERE), or the pollution haven effect: trade openness would reduce the comparative advantage of capital-intensive goods in higher income countries that have relatively strict environmental policies whereas increasing the comparative advantage of such goods in countries with less stringent environmental regulations. This means that laxity is the source of comparative advantage. As a result, the production of capital-intensive goods under more (or less) stringent regulations decreases (increases), and the emissions decrease (increase).

The net effect of the composition effect as a result of trade openness could be positive or negative, depending on the relative sizes of the (KLE) and the (ERE) [5].
The trade-induced technique effect: Trade openness can lead to improvements in techniques of production which generates less pollution emissions. This decline in emission intensity can come about in two ways. First, freer trade will increase the availability and lower the cost of environmentally-friendly goods and technologies. This is particularly important for countries whose domestic industries do not produce these products and technologies in sufficient scale or at lower prices. For exporters, additional market access can provide incentives to develop new products and technologies to mitigate pollution emissions. Second, the increase in income that trade brings about can lead society to demand better environmental quality and less pollution emissions.

Since the scale and technique effects tend to work in opposite directions, and the composition effect depends on the comparative advantage of countries, the overall impact of trade on pollution emissions will depend on the magnitude or strength of each of the three effects. In other words, the net impact of trade liberalization on a country's environment would therefore require a consideration of scale, composition and technology effects.

\section{LITERATURE REVIEW}

The standard inverted U-shaped relationship between income growth and environmental quality is referred to as the environmental Kuznets curve (EKC) hypothesis, which was based on the traditional Kuznets hypothesis and was first described in the seminal study by [9]. By applying EKC theory, earlier studies have provided a better understanding of the environmental consequences of international trade. According to the EKC concept, pollution emissions are expected to have a positive relationship with the level of income or trade liberalization before the EKC threshold (turning point) and then a negative relationship beyond the threshold. For example, if there is a negative relationship between pollution emissions and free trade, then emissions are likely to decrease as the country becomes more exposed to open markets. Similarly, if there is a positive relationship, then the country is not likely to have experienced its optimal level of trade liberalization.

The study by [4] first provides the theoretical structural model of the demand and supply of pollution to empirically explore the determinants of emissions. Assume the $\mathrm{N}$ agents lives in a small open economy that produces two final goods, $X$ and $Y$, with two inputs, labor, $L$, and capital, $K$. Industry $Y$ is labor intensive and does not pollute. Industry $X$ is capital intensive and generates pollution as a by-product. The economy faces trade frictions $\beta$, which influence the price of a product. Pollution policy is determined by the government, which sets a pollution tax $(\tau)$. Given these assumption, total pollution can be expressed as:

$$
\hat{Z}=\hat{S}+\widehat{K / L}-\hat{Y}-\widehat{N}-\hat{\delta}+\widehat{p W}+\hat{\beta}
$$

where "$\wedge$ " denotes "percent change. $Z$ is Pollution emissions variable. Change in demand for pollution now depends on the scale $S$, the capital/labor ratio $K / L$, this is a composition effect, the prices of goods, determined by world price $p^{w}$ and trade frictions $\beta$, the pollution tax $(\tau)$, real income per capita $(Y)$, number of population $N$, the marginal disutility of pollution 
emissions $\delta . Y, N$ and $\delta$ terms all reflect the effects of changes in pollution policy. This is the technique effect. Since trade openness could increase production and income, it affects emissions through the scale effect and the technique effect.
Therefore the study by [4] investigated how openness to international goods markets affects pollution concentrations by using following equation for data on sulfur dioxide $\left(\mathrm{SO}_{2}\right)$ concentration for 43 countries from 1971 to 1996.

$$
\begin{aligned}
& \mathrm{Z}_{\mathrm{i}, \mathrm{t}}=\beta_{0}+\beta_{1} \mathrm{~S}_{\mathrm{i}, \mathrm{t}}+\beta_{2} \mathrm{Y}_{\mathrm{i}, \mathrm{t}}+\beta_{3}\left(\mathrm{Y}_{\mathrm{i}, \mathrm{t}}\right)^{2}+\beta_{4} \mathrm{KL}_{\mathrm{i}, \mathrm{t}}+\beta_{5}\left(\mathrm{KL}_{\mathrm{i}, \mathrm{t}}\right)^{2}+\beta_{6} \mathrm{O}_{\mathrm{i}, \mathrm{t}}+\beta_{7} \mathrm{O} .(\mathrm{RY})_{\mathrm{i}, \mathrm{t}} \\
& +\beta_{8} \mathrm{O} .(\mathrm{RY})_{\mathrm{i}, \mathrm{t}}^{2}+\beta_{9} \mathrm{O} .(\mathrm{RKL})_{\mathrm{i}, \mathrm{t}}+\beta_{10} \mathrm{O} .(\mathrm{RKL})_{\mathrm{i}, \mathrm{t}}^{2}+D_{1}+D_{2}+\ldots .+T+\varepsilon_{\mathrm{i}, \mathrm{t}} .
\end{aligned}
$$

where the scale effect $\mathrm{S}$ variable is measured as GDP per squared kilometer GDP/ $/ \mathrm{km}^{2}$, since (ACT) is usually applied on data at the city/station level. The term $Y$ is one period lagged three years moving average of GDP per capita in constant prices: $Y=\left(\mathrm{GDP}_{(-1)}+\mathrm{GDP}_{(-2)}+\mathrm{GDP}_{(-3)}\right) / 3$. The use of $Y$ and $Y^{2}$ to capture scale and technique effects is consistent with the reduced-form approach in testing the environmental Kuznets curve.

The term KL is the capital/labor ratio and used to represent the composition effect. The square of the capital-labor ratio $(K L)^{2}$ is included to allow capital accumulation to have a diminishing effect on the pollution.

The term $O$ is measured as the ratio of total exports and imports to GDP as trade openness variable (trade intensity). This term captures the terms $p^{w}$ and $\beta$ in equation (1). To test the comparative advantage effects associated with trade frictions, a country's capital-labor ratio and per capita income levels are expressed as relative to the world average for each year. Relative income (RY) and relative capital-labour ratio (RKL) are the variables $Y$ and $\mathrm{KL}$ of country i divided by the corresponding world variable for the given year, respectively.

The terms $O(\mathrm{RKL})$ and $O(\mathrm{RKL})^{2}$ are interaction of openness with country's (RKL) and its square. The term $O(\mathrm{RY})$ and $O(\mathrm{RY})^{2}$ are interactions of openness with country's RY and its square, respectively. The term O.RY reflects the environmental regulations effect ERE, or the pollution haven effect, whereas the term O.RKL reflects the capital-labor effect KLE or the factor endowment hypothesis.

The quadratic terms for these interacted variables, O. $(\mathrm{RKL})^{2}$ and O.(RY) ${ }^{2}$ are included. It is expected that an increase in trade intensity would be associated with rising pollution for a country with a high (RKL) ${ }^{2}$ and with falling pollution for those with lower (RKL) ${ }^{2}$. Similarly, trade liberalization is expected to increase pollution for countries with low $(\mathrm{RY})^{2}$ and reduce pollution for those with high $(\mathrm{RY})^{2} . D_{1}, D_{2} \ldots$ are dummy variables and $T$ is time trend. $\epsilon_{i, t}$ is an error term.

The study conducted by [4] concluded that the technique-effect elasticity was consistently higher than the scale effect. It has been shown that trade-induced composition has positive environmental effects. Therefore, they conclude that free trade is good for the environment.

The study by [5] estimated the equation used by [4] using country-level emissions per capita of $\left(\mathrm{SO}_{2}\right)$ and nitrogen oxides (NOx) for 26 developed and developing countries from 1975 to 1990, carbon dioxide $\left(\mathrm{CO}_{2}\right)$, and biochemical oxygen demand (BOD) for 32 developed and developing countries from 1975 to 1995 . They excluded scale measure variable $(\mathrm{S})$ from the estimated equation, used one period lagged per capita income $Y$ as the scale-technique effect and added the interaction term (Y.KL) and the term (O.RY.RKL) in this equation. They find that regulations differentials do influence intra - and inter-industry trade shares.

The study by [6] estimated the same equation of [5], but they included a logged term of the dependent variable $L n Z_{i, t}$ as independent variable, to control for the effect of the dynamic process. They analyzed the impact of trade liberalization on $\mathrm{SO}_{2}, \mathrm{CO}_{2}$, and $\mathrm{BOD}$ by using data on 90 countries from 1960 to 2000 . They find that a $1 \%$ increase in trade openness decreases $\mathrm{SO}_{2}, \mathrm{CO}_{2}$, and BOD by 1.22, 0.77, and 0.05 percent, respectively, thus, trade openness is good for the environment.

The studies by [12]-[14] indicate that there is weak statistically significant relation between trade and $\mathrm{CO}_{2}$. On the other hand, the studies conducted by [15]-[20] indicate that that trade openness rate of developed countries has a negative effect on the level of $\mathrm{CO}_{2}$ emission whereas trade openness rate of developing and less developed countries has positive effect.

From the earlier studies, we note that all studies expanded in use a large number of independent variables (as a level), it's squared and interactions of these variables in regression equation. Moreover, they used only fixed or random effects models for estimation. Many difficulties tend to arise when there are more than five independent variables in a regression equation. One of the most frequent is the problem that two or more of the independent variables are highly correlated to one another. This is called structural multicollinearity problem. Second: Fixed and random effects models are used when the number of countries (group) large and very short period, small $T$ and large $N$ panels, then they ignored the impact of the dynamic changes that resulting from the length of the sample period.

\section{Model, DATA AND ECONOMETRIC Metodology}

\section{A. The Model}

This paper uses a specification similar with the one used in study [4], which estimate the country-level data equation. Some of the squared variables used in previous equations are excluded from estimated equation because we are not able to explain the intuition behind the results regarding those variables. The most important reason is that the inclusion of these variables leads to the structural multicollinearity problem. To solve these problems, this paper estimates the following equation for the two groups of countries, each group having similar characteristics and policies:

$$
\begin{aligned}
& \ln \mathrm{Z}_{\mathrm{i}, \mathrm{t}}=\theta_{0}+\theta_{1} \ln \mathrm{Y}_{\mathrm{i}, \mathrm{t}}+\theta_{2}\left(\ln \mathrm{Y}_{\mathrm{i}, \mathrm{t}}\right)^{2}+\theta_{3} \operatorname{lnKL} \mathrm{i}_{\mathrm{i}, \mathrm{t}}+\theta_{4}\left(\operatorname{lnKL}_{\mathrm{i}, \mathrm{t}}\right)^{2}+\theta_{5} \ln \mathrm{O}_{\mathrm{i}, \mathrm{t}}+\theta_{6} \ln \mathrm{O} .(\mathrm{RY})_{\mathrm{i}, \mathrm{t}} \\
& +\theta_{7} \ln \mathrm{ln} .(\mathrm{RKL})_{\mathrm{i}, \mathrm{t}}+T+\varepsilon_{\mathrm{i}, \mathrm{t}} .
\end{aligned}
$$

First group: developed countries (Australia, Austria, Belgium, Canada, Denmark, France, Greece, Italy, Japan, 
Netherlands, Norway, Spain, Sweden, United Kingdom, United States) with a high relative income (RY) ${ }^{2}$ and a high relative capital-labour ratio(RKL) ${ }^{2}$. Second group: developing countries(Algeria, Cameroon, Cote d'Ivoire, Egypt, India, Jordan, Morocco, Nigeria, Pakistan, Tunisia) with a low $(\mathrm{RY})^{2}$ and a low $(\mathrm{RKL})^{2}$. Developed countries are likely to be both capital abundant and have stricter pollution policy than developing countries.

It is expected that an increase in trade intensity would be associated with rising pollution for a country with a high $(\mathrm{RKL})^{2}$ and with falling pollution for those with lower $(\mathrm{RKL})^{2}$. Similarly, trade liberalization is expected to increase pollution for countries with low $(\mathrm{RY})^{2}$ and reduce pollution for those with high (RKL) ${ }^{2}$

All variables, in equation (3), are entered as a logarithm form. The dependent variable $Z_{i, t}$ is the carbon dioxide $\mathrm{CO}_{2}$ emissions per capita of country $i$ in year $t$. The coefficient $\theta_{0}$ is the group-specific effect. The specification of explanatory variables is the same as used in equation(2). The elasticity of the $Z$ with respect to $Y$ could be positive $\theta_{1}>0$ or negative $\theta_{1}<0$ as a measure of scale- technique effect. The effect of square income must be negative $\theta_{2}<0$.. The partial effect of $Y$ on the dependent variable $Z$ is equal to $\theta_{1}+\theta_{2} \operatorname{Ln} Y_{i, t}$. The elasticity of capital labour ratio KL is positive $\theta_{3}>0$ for developed countries and negative $\theta_{3}<0$ for developing countries. The effect of square capital labour ratio $(\mathrm{KL})^{2}$ could be negative $\theta_{4}<0$ or positive $\theta_{4}>0$. The partial effect of KL on the variable $\mathrm{Z}$ is equal $\theta_{3}+\theta_{4} L n K L_{i, t}$.

The sign of trade intensity could be positive $\theta_{5}>0$ for developing countries and negative $\theta_{5}<0$ for developed countries. It is expected that $\theta_{6}<0$ and $\theta_{7}>0$ for developed countries, since trade liberalization is expected to decrease pollution for countries with high relative income and to increase pollution for countries with high relative capital-labour ratio. In the other hand, It is expected that $\theta_{6}>0$ and $\theta_{7}<0$ for developing countries with low relative income and low relative capital-labour ratio.

\section{B. Data}

The data for $\mathrm{Y}, \mathrm{Z}$ and $\mathrm{O}$ variables have been obtained from the World Development Indicators, WDI 2016 (http://publications.worldbank.org/wdi) [21]. The $Y$ is one period lagged three years moving average of GDP per capita in constant 2011 national prices in million US\$, the term $O$ is measured as the ratio of total exports and imports to GDP and the $Z$ is the carbon dioxide $\mathrm{CO}_{2}$ emissions per capita. The capital/labor ratio $\mathrm{KL}$ is the capital stock at constant 2011 national prices in million US\$ divided by the number of persons engaged (in millions) from Penn World Table, PWT, version 9.0: (http: //pwt.econ.upenn.edu/php_ site / pwt63/ pwt63_form .php) [16]. Relative income (RY) and relative capital-labour ratio (RKL) are the variables $Y$ and $\mathrm{KL}$ of country $i$ divided by the corresponding world variable for the given year, respectively.

\section{Econometric Methodology}

Panel models based on the traditional random effect (FE) or fixed effect (RE) models generally focus on small $\mathrm{T}$ and large $\mathrm{N}$ panels and allow intercept heterogeneity across countries whereas assuming slopes to be the same. No distinction is made between the short run and the long run either in the (FE) or the (RE) estimation. On the other hand, the Autoregressive Distributed Lag ARDL approach makes a distinction between the short run and the long run, but cannot resolve the problem of either short run heterogeneity or long run convergence. Recent papers by [7],[8] offer two important new techniques to estimate nonstationary dynamic panels in which the parameters are heterogeneous across groups: the mean-group (MG) and pooled mean-group (PMG) estimators.

The (MG) estimator relies on estimating a separate equation for each country whereas the coefficients for the whole panel are computed as unweighted averages of the individual coefficients. The (PMG) estimator considers a lower degree of heterogeneity since it imposes homogeneity in the long run coefficients whereas still allowing for heterogeneity in the short run coefficients and the error variances. The basic assumptions of the PMG estimator are: i) the error terms are serially uncorrelated and are distributed independently of the regressors, i.e., the explanatory variables can be treated as exogenous; ii) there is a long run relationship between the dependent and explanatory variables; and iii) the long run parameters are the same across countries. It is also possible to test for the suitability of the (PMG) estimator relative to the (MG) estimator based on the consistency and efficiency properties of the two estimators, using a Hausman test.

Assume an autoregressive lag (ARDL) $(1,1,1,1,1,1,1,1)$ Dynamic panels Specification of the form:

$$
\begin{aligned}
& L n Z_{i, t}=\gamma_{i}+\lambda_{i} \operatorname{LnZ} Z_{i, t-1}+\delta_{10 i} L n Y_{i, t}+\delta_{11 i} \operatorname{Ln} Y_{i, t-1}+\delta_{20 i}\left(\operatorname{LnY} Y_{i, t}\right)^{2}+\delta_{21 i}\left(\operatorname{Ln} Y_{i, t-1}\right)^{2}+\delta_{30 i} \operatorname{LnK} L_{i, t}+\delta_{31 i} \operatorname{LnKL_{i,t-1}} \\
& +\delta_{40 i}\left(\operatorname{LnKL} L_{i, t}\right)^{2}+\delta_{41 i}\left(L n K L_{i, t-1}\right)^{2}+\delta_{50 i} L n O_{i, t}+\delta_{51 i} \operatorname{LnO} O_{i, t-1}+\delta_{60 i} \operatorname{LnO} R Y_{i, t}+\delta_{61 i} \operatorname{LnO} R Y_{i, t-1} \\
& +\delta_{70 i} \operatorname{LnO} \cdot R K L_{i, t}+\delta_{71 i} \operatorname{LnO} \cdot R K L_{i, t-1}+\varepsilon_{i, t}
\end{aligned}
$$

where the number of groups $i=1,2, \ldots, N$; the number of periods $t=1,2, \ldots T ; \delta_{i j}$ are the coefficients vectors; and $\gamma_{i}$ is the group-specific effect. It is common to reparameterize

$$
\begin{aligned}
& \Delta L n Z_{i, t}=\varphi_{i}\left[\operatorname{LnZ} Z_{i, t-1}-\theta_{0 i}-\theta_{1 i} \operatorname{LnY}_{i, t}-\theta_{2 i}\left(\operatorname{Ln} Y_{i, t}\right)^{2}-\theta_{3 i} \operatorname{LnKL}_{i, t}-\theta_{4 i}\left(\operatorname{LnKL_{i,t}}\right)^{2}-\theta_{5 i} \operatorname{LnO}_{i, t}-\theta_{6 i} \operatorname{LnO} \cdot R Y_{i, t}-\theta_{7 i} \operatorname{LnO} \cdot R K L_{i, t}\right] \\
& +\delta_{10 i} \Delta \operatorname{Ln} Y_{i, t}+\delta_{20 i} \Delta\left(\operatorname{Ln} Y_{i, t}\right)^{2}+\delta_{30 i} \Delta L n K L_{i, t}+\delta_{40 i} \Delta\left(\operatorname{LnKL} L_{i, t}\right)^{2}+\delta_{50 i} \Delta \operatorname{LnO} O_{i, t}+\delta_{60 i} \Delta \operatorname{LnO} \cdot R Y_{i, t}+\delta_{70 i} \Delta \operatorname{LnO} \cdot \mathrm{RKL}_{i, t} \\
& +\varepsilon_{i, t}
\end{aligned}
$$

where: $\theta_{i}$ are the long-run relationships between the variables. 
$\theta_{0 i}=\frac{\gamma_{i}}{1-\lambda_{i}}, \quad \theta_{1 i}=\frac{\delta_{10 i}+\delta_{11 i}}{1-\lambda_{i}}, \theta_{2 i}=\frac{\delta_{20 i}+\delta_{21 i}}{1-\lambda_{i}}, \theta_{3 i}=\frac{\delta_{30 i}+\delta_{31 i}}{1-\lambda_{i}}, \quad \theta_{4 i}=\frac{\delta_{40 i}+\delta_{41 i}}{1-\lambda_{i}}, \theta_{5 i}=\frac{\delta_{50 i}+\delta_{51 i}}{1-\lambda_{i}}, \quad \theta_{5 i}=\frac{\delta_{50 i}+\delta_{51 i}}{1-\lambda_{i}}$ and $\theta_{7 i}=\frac{\delta_{70 i}+\delta_{71 i}}{1-\lambda_{i}}$,

The parameter $\phi_{i}$ is the error-correcting speed of adjustment term $\phi_{i}=-\left(1-\lambda_{i}\right)$. If $\phi_{i}=0$, then there would be no evidence for a long-run relationship. The $\phi_{i}$ is expected to be significantly negative under the prior assumption that the variables show a return to a long-run equilibrium.

\section{EMPIRICAL RESULTS}

Using the logarithms of the variables, this paper runs two estimations; Mean Group (MG) and Pooled Mean Group (PMG) models for 15 developed countries and 10 developing countries.

From Table I, the probability of Hausman statistic is higher than 0.05 . Here we conclude that the (PMG) estimator, the efficient estimator under the null hypothesis, is preferred over the MG model. Table I provides the results from Equation (5) for two groups.

\section{A. The Scale and Technique Effect}

In the long -run, the effect of the income variable $\operatorname{LnY}$ on $\mathrm{LnZ}$ (carbon dioxide $\mathrm{CO}_{2}$ emissions) is positive and significant, $\theta_{1}=3.09, \theta_{1}=0.48$, and the effect of the squared income $(\mathrm{LnY})^{2}$ on $\mathrm{CO}_{2}$ is negative and significant, $\theta_{2}=-0.48$, -0.23 for developed and developing countries, respectively. This is a scale and technique effect. The estimating elasticities reveal that scale effect dominates the technique effect. Many studies [5], [22], [23] attribute this result to the fact that $\mathrm{CO}_{2}$ emissions have not been subjected to the same degree of regulation as other air pollutants, such as the sulphur dioxide concentrations. As a result, $\mathrm{CO}_{2}$ emissions have been increasing steadily with economic growth.

The partial effect of income $\operatorname{LnY}$ on the $\mathrm{CO}_{2}$ emission for developed countries equal (3.09 - 0.96LnY), therefore, the effect of the $\operatorname{LnY}$ remains positive as long as $\operatorname{LnY}$ is smaller than 3.219. In our sample, the average value of the $\operatorname{LnY}$ is 3.479 for this group, Table II. With all else equal, on average, $\mathrm{CO}_{2}$ emission for all developed countries decreases as output (per capita) grows. For developing countries, the partial effect of the $\operatorname{Ln} Y$ equal $(0.82-0.46 \operatorname{Ln} Y)$, therefore, the effect of the $\operatorname{Ln} Y$ remains positive as long as $\operatorname{Ln} Y$ is smaller than 1.783. In our sample, the maximal value of the $\operatorname{Ln} Y$ is 1.509 for this group. This result indicates that $\mathrm{CO}_{2}$ emission for all developing countries increases as output (per capita) grows.

TABLE I: LONG-RUn Elasticities of ARDL $(1,1,1,1,1,1,1,1)$ DEPENDENT VARIABLE LN Z

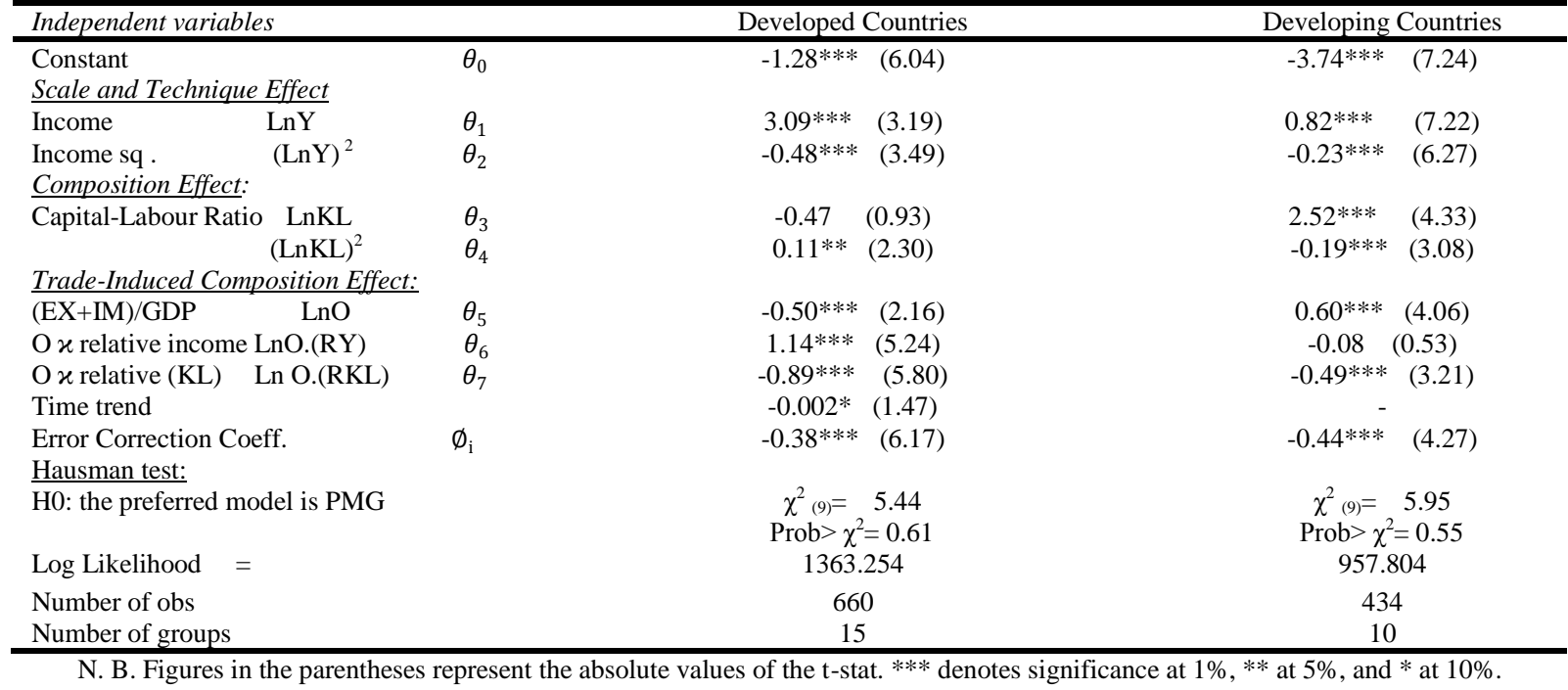

TABLE II: DESCRIPTIVE STATISTICS

\begin{tabular}{|c|c|c|c|c|c|c|c|c|c|c|}
\hline \multicolumn{6}{|c|}{ Developed Countries } & \multicolumn{5}{|c|}{ Developing Countries } \\
\hline & Mean & $\operatorname{Max}$ & Min & Std. Dev. & Obs. & Mean & Max & Min & Std. Dev. & Obs. \\
\hline $\operatorname{Ln} Y$ & 3.479 & 4.508 & 2.443 & 0.362 & 660 & 0.411 & 1.509 & -1.026 & 0.611 & 433 \\
\hline $\operatorname{LnO}$ & 3.943 & 5.100 & 2.373 & 0.524 & 660 & 3.949 & 5.007 & 2.019 & 0.540 & 433 \\
\hline
\end{tabular}

\section{B. The Composition Effect}

The capital-labor ratios $\operatorname{Ln}(K L)$ coefficient is positive, large and significant for developing countries. This indicates the strong evidence for the composition effect. Whereas this effect of $\mathrm{Ln}(K L)^{2}$ on $\mathrm{CO}_{2}$ is positive and significant for developed countries, and negative and significant for developing countries, therefore, capital accumulation generating shifts toward dirty industries for developed countries and shifts toward clean industries for developing countries. For developing countries, the partial effect of the
LnKL equal (2.52 - 0.38LnY), therefore, the effect of the $\operatorname{Ln} Y$ remains positive as long as $\operatorname{Ln} Y$ is smaller than 6.632. In our sample, the maximal value of the $\operatorname{Ln} K L$ is 5.270 for this group. This result indicates that $\mathrm{CO}_{2}$ emission for all developing countries increases as $\mathrm{K} / \mathrm{L}$ ratios grows.

\section{Trade-Induced Composition Effect}

The long-run elasticity $(\operatorname{Ln} O)$ is negative and significant for developed countries $\theta_{5}=-0.5$, A $1 \%$ increases in trade openness decreases pollution by $0.5 \%$. This result mean 
emissions are likely to decrease as the developed countries become more exposed to open markets. Elasticity of the $(\mathrm{LnO})$ is positive for developing countries $\theta_{5}=0.6$. A $1 \%$ increases in trade openness leads to $0.6 \%$ increases in pollution for developing countries, then, this group is not likely to have experienced its optimal level of trade liberalization.

For developed countries, the effect of the $\operatorname{Ln}\left(O^{*} R Y\right)$ is positive and significant, $\theta_{6}=1.14$. Whereas the effect of the $\mathrm{Ln} O(R K L)$ is negative and significant, $\theta_{7}=-0.9$ These results are unexpected and not consistent the expectations of our model, because for high-income country, with a high level of environmental regulations, pollution will fall in response to trade liberalization. Also, it is expected that a high-income country with abundant capital to have a comparative advantage in the production and export of capital-intensive goods (i.e., pollution goods) and, therefore, to produce more emissions.

For developing countries, with a low relative income and capital-labour ratio, the effect of the $\operatorname{Ln}(O * R Y)$ is insignificant. This means that there is no environmental regulations effect in the case of developing countries. But the effect of the $\operatorname{Ln} O(R K L)$ is negative and significant, $\theta_{7}=-0.5$. These results indicate that no evidence for environmental regulations Effect ERE or capital labour ratio effect KLE for all countries. However, these results are consistence with the finding of [5] for $\mathrm{CO}_{2}$ emission. They find no support for both the ERE and KLE and this reflect the lack of regulations directly aimed at $\mathrm{CO}_{2}$ emissions or, $\mathrm{CO}_{2}$ intensive sectors have not directly faced pressures to relocate.

Time trend has played an important role in influencing the signs and make all the elasticities insignificant, especially for developing countries. Moreover, time trend was not significant. For developed countries, time trend has negative effect on the level of $\mathrm{CO}_{2}$ emission, although it has weak significant, implying that factors which are common to all countries, but which change over time, are reducing emissions.

Finally, as a shown in Table I, the coefficients of the speed of adjustment term $\varphi_{i}$ are significant at the $1 \%$ level, as expected, for two groups. The speed of adjustment toward long-run equilibrium for developing countries (44\%) appears faster than in the case of developed countries (38\%).

\section{Sensitivity Analysis of the PMG Results}

We also conducted a sensitivity analysis of the PMG results to changes in the lag structure of the dependent and independent variables by re-estimating the regression using the Akaike (AIC) criterion to select the ARDL specification for each group, imposing a maximum lag order of 3 in order to maintain a reasonable number of degrees of freedom. Table III shows the results for this specification with the different estimation procedures.

TABLE III: LONG-RUN ElASTICITIES OF ARDL(3, 3, 3, 3, 3, 3, 3, 3)DEPENDENT VARIABLE LN Z

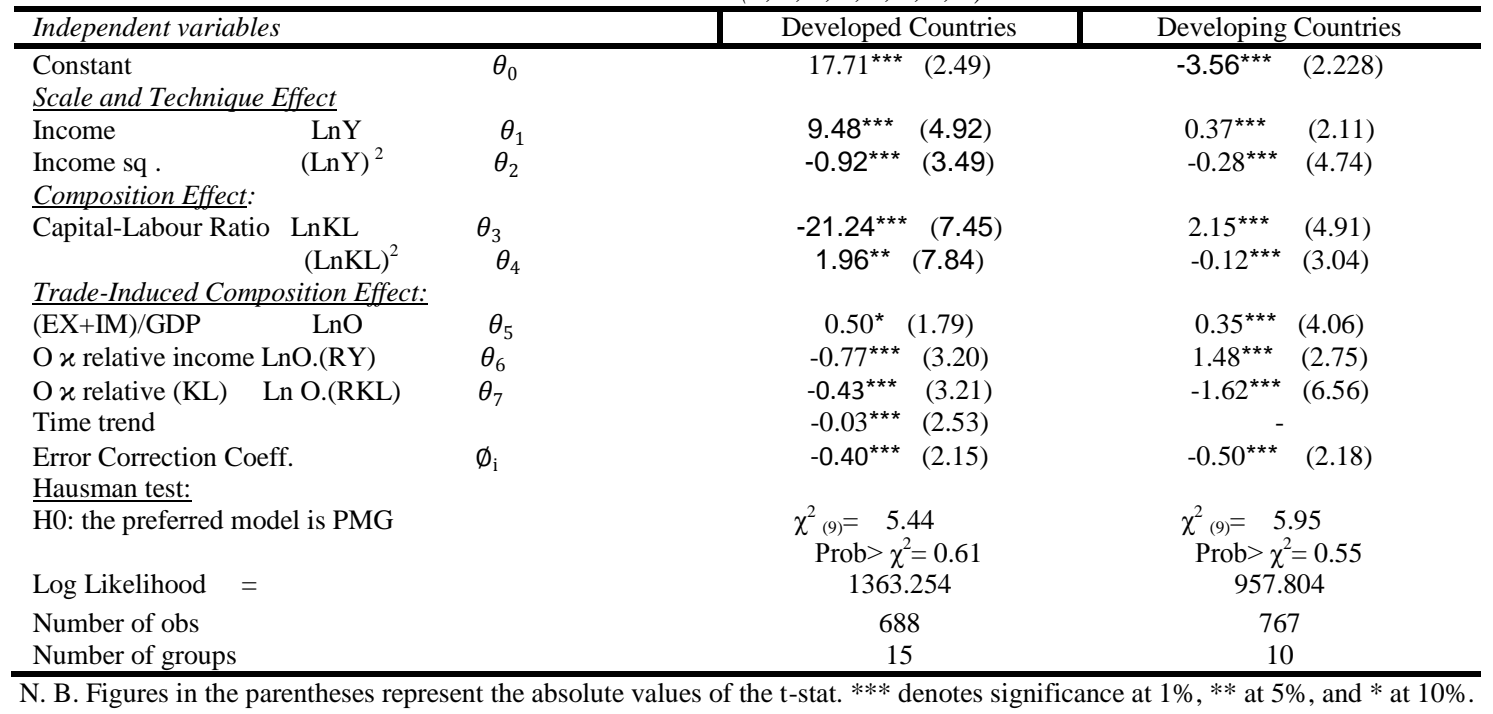

The results show some sensitivity to the choice of the lag order. For developed countries, the effect of the interaction trade intensity and relative income $\operatorname{Ln}\left(O^{*} R Y\right)$ is now both positive and significant, as expected. Trade openness would increase the comparative advantage of such goods in countries with less stringent environmental regulations. This means that laxity is the source of comparative advantage for developing countries.

For developed countries, the results concerning the coefficient the interaction trade intensity and relative income $\mathrm{Ln}(\mathrm{O} * \mathrm{RY})$ were improved: now the coefficient is negative and significant as expected. The results concerning composition effect $\operatorname{lnKL}$ are, however, worse since the respective coefficient is now significant but not positive. The most problematic result concerns the trade intensity coefficient, which is now positive and weak significant.

\section{CONCLUSION}

The aim of this paper was to evaluate the long run overall effects of trade openness on pollution measured by carbon dioxide $\mathrm{CO}_{2}$ emissions for 16 developed countries and 18 developing countries over the period 1970-2013. This paper focused first on theoretical framework developed by [4]. An important contribution of this framework has been the formal decomposition of the environmental impact of trade into the scale, technique and composition effects.

By applying the pooled mean group PMG estimator, the paper found a positive and significant relationship between income and carbon dioxide emissions $\mathrm{CO}_{2}$, in the long -run. 
The estimating elasticities reveal that scale effect dominates the technique effect for developed and developing countries. The effect of the income squared on $\mathrm{CO}_{2}$ is negative and significant. These results supported the Environmental Kuznets Curve Hypothesis EKC for two groups.

The empirical results indicated that there is no evidence for composition effect $(\mathrm{K} / \mathrm{L})$ for developed and developing countries. Whereas the impact of the $(\mathrm{K} / \mathrm{L})^{2}$ was positive and significant. This result means that the accumulation of capital leads to increased pollution in the long run all countries

Trade openness of developed countries has a negative effect on the level of $\mathrm{CO}_{2}$ emission, whereas trade openness of developing countries has positive effect. The results may be evidence that the Pollution Haven Hypothesis is still valid for the developing countries.

The effect of the interaction trade intensity and relative income $\operatorname{Ln}\left(O^{*} R Y\right)$ and, the interaction trade intensity and relative capital labour ratio $\mathrm{LnO}(R K L)$ on emission was unexpected and not consistent the expectations of our model for the developing countries.

With regard to developing countries, with a low relative income and capital-labour ratio, the effect of the $\operatorname{Ln}\left(O^{*} R Y\right)$ and $\operatorname{LnO}(R K L)$ are negative and significant. The effect of the $\mathrm{LnO}(R K L)$ is consistence with our model, whereas The effect of the $\operatorname{LnO}(R Y)$ is not expected.

The speed of adjustment toward long-run equilibrium for developing countries appears much faster than in the case of developed countries.

\section{REFERENCES}

[1] World Trade Organization International, “Trade statistics 2015," Special Focus: World Trade and The WTO, 1995-2014.

[2] J. G. J. Olivier, G. M, M. Janssens-Maenhout, and J. A. H. W. Peters, "Trends in global $\mathrm{CO}_{2}$ emissions: 2015 report," Hague: PBL Netherlands Environmental Assessment Agency; Ispra: European Commission, Joint Research Centre, 2015.

[3] R. Zaman, " $\mathrm{CO}_{2}$ Emissions, Trade openness and GDP per capita: Bangladesh perspective," Munich Personal RePEc Archive, No. 48515, pp. 5-6, World Bank, 2012.

[4] W. Antweiler, B. R. Copeland, and M. S. Taylor, "Is free trade good for the environment," American Economic Review, vol. 91 no. 4, pp. 877-908, 2001.

[5] M. A. Cole and R. J. R. Elliott, "Determining the trade-environment composition effect: The role of capital, labor and environmental regulations," Journal of Environmental Economics and Management, vol.46, no. 3, pp. 363-383, 2003.

[6] S. Managi, A., Hibiki, and T. Tsurumi, "Does trade liberalization reduce pollution emissions?" RIETI Discussion Paper Series, no. 08-E-013, 2008.

[7] M. H. Pesaran, Y. Shin, and R. P. Smith, "Estimating long-run relationships in dynamic heterogeneous panels," DAE Working Papers Amalgamated Series, no. 9721, 1997.
[8] Pooled mean group estimation of dynamic heterogeneous panels, Journal of the American Statistical Association, vol. 94, pp. 621-634, 1999.

[9] G. M. Grossman and A. B. Krueger, "Economic growth and the environment," Quarterly Journal of Economics, vol. 110, pp. 353-357, 1995.

[10] B. R. Copeland and M. S. Taylor, "North-south trade and the environment," Quarterly Journal of Economics, vol. 109, pp. 755-787, 1994.

[11] B. R. Copeland and M. S. Taylor, "Trade, growth, and the environment," Journal of Economic Literature, Vol. XLII, pp. 7-71, March 2004

[12] J. Frankel and A. Rose, "Is trade good or bad for the environment? Sorting out the causality," Review of Economics and Statistics, vol. 87, no. 1, pp. 85-91, 2005.

[13] E. Choi, A. Heshmati, and Y. Cho, "An empirical study of the relationships between $\mathrm{CO}_{2}$ emissions," Economic Growth and Openness, IZA Discussion Paper No. 5304, 2010.

[14] Z. Eléazar, " $\mathrm{CO}_{2}$ emissions, growth, energy consumption and foreign trade in Sub-Sahara African countries," Document de Travail Working Paper, EA 4272, 2015.

[15] J. L. Hering and S. Poncet, "Has trade openness reduced pollution in China?" CEPII Working Paper, 2015.

[16] S. Bekmez and F. N. Ozsoy, "The relation between environmental pollution and trade: a panel data analysis," Journal of Agriculture and Environment for International Development, JAEID, vol. 110, no. 1, 2016.

[17] A. C. Serhat, "The impact of foreign trade, energy consumption and income on $\mathrm{CO}_{2}$ emissions," International Journal of Energy Economics and Policy, vol. 4, no. 3, pp. 465-475, 2014.

[18] S. T. Komail and S. Younespour, "The effect of trade openness on environmental quality: Evidence from Iran's Trade relations with the selected countries of the different blocks," Iranian Economic Review, vol. 16, no. 32, Spring 2012.

[19] J. V. G. Silvina and D. M. Liverman, "Scale, technique and composition effects in the mexican agricultural sector: The influence of nafta and the institutional environment," in Proc. Third North American Symposium on Assessing the Environmental Effects of Trade, Montreal, 30 November - 1 December 2005.

[20] J. Yanqing, "Openness, economic development, and the environment in post-reform China: A model with empirical analysis," International Journal of Social Science Studies, vol. 2, no. 3, 2014.

[21] World Bank, "World Development Indicators (WBI 2016)," CD-ROM, Washington, D.C., 2016

[22] R. C. Robert, R. Inklaar, and M. P. Timmer "The next generation of the Penn world table," American Economic Review, vol. 105, no. 10, pp. 3150-3182, 2015.

[23] P. Mitsis, "Is there an environmental kuznets curve in the carbon dioxide emissions?" Discussion Paper, no. 16-2012, 2012.

[24] L. Aydın, "Intra-BRICS Trade opening and its implications for carbon emissions: A general equilibrium approach," Journal of Economics and Development Studies, vol. 4, no. 2, pp. 207-218, June 2016.

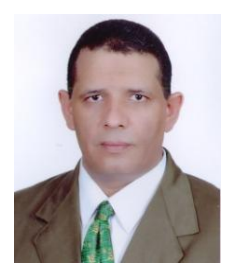

Elsayed Mettwally Abd-Elkader was born in El-Shrqia, Egypt. He has received $\mathrm{MS}$ and $\mathrm{PhD}$ degrees in economics of foreign trade from Helwan University, Egypt.

He has been interested in macro economics and econometrics.

$\mathrm{He}$ is working as an assistant professor of economics at High Institute for Computer \& Management Science, 15 Mauo Street- Shoubra-Al Khaimah, Cairo, Egypt. 